\title{
Beyond Vocational High School and Corporate Cooperation: A Social Exchange Perspective in Education
}

\author{
Nunuk Hariyati \\ Educational Management \\ State University of Surabaya \\ Surabaya, Indonesia \\ nunukhariyati@unesa.ac.id
}

\author{
A. Sonhadji \\ Graduate School \\ State Univeristy of Malang \\ Malang, Indonesia \\ asonhadjikh@yahoo.com
}

\begin{abstract}
Most of social life involves interaction between individuals and group, included school and individuals or corporate actors, can be viewed as social exchange. It is assumed as Social Exchange Theory. This study focused on three Vocational High Schools which have good records with some big corporates in Mojokerto: State Vocational High School 1 Mojokerto, Taman Siswa Vocational High School, and PGRI Vocational High School. This study shows us social behavior of vocational school and corporate in reinforcing each other's behavior to accomplish their goals. Reward and cost play a key role in social relation moreover in the forms of organization social behavior. In this context Vocational High Schools have bargaining power that causes the relation between two parties can be tangible or intangible, and more or less rewarding or costly. Both cost and reward determine whether the social relation will be continued or not.
\end{abstract}

Keywords: vocational high school, corporates, social exchange

\section{INTRODUCTION}

Since the free-market policies in the ASEAN region or ASEAN Free Trade Area (AFTA) had to compete with various including industrial sectors or the sector Business and Industry. Competent workforce becomes one of the main capital in maintaining the existence of the industry were also affected by the AFTA. Business and Industry compete to recruit skilled human resources and in accordance with the needs of Business and Industry at this time.

It became a big task of establishment vocational education in Indonesia, especially vocational schools (SMK), to produce prospective workforce who meet the needs of Business and Industry. Vocational school should emphasize the transfer of knowledge, transfer of skills, and the transfer of real life so the students as candidates for employment have better preparation to compete and face the real working conditions in the field. All the three mentioned aspect can be obtained through the Dual System Education (PSG) in which to maximize establishment vocational education which cooperate with Business and Industry.

Cooperation conducted by vocational schools and vocational schools made an effort to meet the needs of both parties.
It refers to the nature of ideal cooperation and balanced i.e: the presence productive exchange. If vocational school wants a place to improve the competence of learners and distribute its graduates, the Business and Industry is also obtain the advantage of a good image, qualified human resources, and other things that become a necessity business and industry at present and future.

It is important to emphasize to organize good cooperation between vocational high school and businessindustry issues a cost in accordance with the expected reward. Keep in mind that both of them have a different orientation, vocational school is a non-profit oriented organization and business and industry as a profit-oriented organization. The different orientation often lead to cooperation between vocational high school and businessindustry but it emerges another problem i.e. do not meet the one's or even both parties' purpose.

The concept of Social Exchange Theory is used to describe the researcher perspective illustrate the complexity of vocational school cooperation with business and industry which has been the classic problem faced by vocational school in general. In theory, there are principles that must be met and the factors that influence a social relationship in the individuals' context and organizations.

In an effort to obtain the real conditions of implementation of cooperation vocational high schools and business- industry in the field, researchers chose three schools i.e.: Vocational High School 1 Mojokerto, Taman Siswa Vocational High School Magersari, PGRI Vocational High School Mojokerto which are industrial cities in Mojokerto, East Java. All of these Vocational High School are favourite that has a list of cooperation with small to large-scale business and industry. Researchers reveal how vocational school as non-profit-oriented organizations have a strong influence and gaining trust of profit oriented business and industry to consduct mutually beneficial cooperation.

\section{II.METHOD}

Researcher uses a qualitative approach and the type of research is multi cases study studies. This study emphasizes on a holistic picture of the pattern of cooperation between 
vocational school built with business- industry in the perspective of the Social Exchange Theory. Multi cases study design obtain what is seen as a comparative study. According to $\mathrm{Yin}^{1}$ double case study enables the researcher to explore the differences that exist within and between existing cases.

Researchers chose three vocational schools in Mojokerto East Java Indonesia, researchers chose three schools i.e.: Vocational High School 1 Mojokerto, Taman Siswa Vocational High School Magersari, PGRI Vocational High School Mojokerto Mojokerto, Researchers Rationale is Mojokerto because the constant growth of business-industry in Mojokerto makes it one of the major industrial cities in Indonesia. Here is the Table I, which describes the growth of industry in Mojokerto.

TABLE I. MOJOKERTO INDUSTRIAL CITY GROWTH (SOURCE: MOJOKERTO BPS)

\begin{tabular}{|c|c|c|c|c|}
\hline \multirow{2}{*}{$\begin{array}{l}\text { Industry } \\
\text { group }\end{array}$} & \multicolumn{4}{|c|}{ AMOUNT } \\
\hline & $\begin{array}{l}\text { Business } \\
\text { unit }\end{array}$ & Labor & $\begin{array}{l}\text { Value of } \\
\text { Production }\end{array}$ & Infestation \\
\hline Big & 3 & 1077 & $205,413.80$ & 35799.86 \\
\hline Moderate & 44 & 46164 & $1,903,894.45$ & $1,109,673.33$ \\
\hline Small & 806 & 6,663 & $180,337.49$ & 35122.63 \\
\hline Micro & 1277 & 12816 & 28541.70 & 1168.93 \\
\hline
\end{tabular}

This research is not only seen from the difference research site, but also a substantial difference in it. The different characteristics of the three-background research, which is described in Table II below.

TABLE II. RESEARCH BACKGROUND CHARACTERISTICS

\begin{tabular}{|c|c|c|c|c|}
\hline \multirow[b]{2}{*}{ No. } & \multirow[b]{2}{*}{ Aspect } & \multicolumn{3}{|c|}{ SCHOOL NAME } \\
\hline & & $\begin{array}{c}\text { Vocational } \\
\text { High } \\
\text { School } 1 \\
\text { Mojokerto }\end{array}$ & $\begin{array}{c}\text { PGRI Vocational } \\
\text { High School } \\
\text { 'Mojokerto }\end{array}$ & $\begin{array}{c}\text { Taman Siswa } \\
\text { Vocational } \\
\text { High School } \\
\text { Magersari }\end{array}$ \\
\hline 1 & $\begin{array}{l}\text { school } \\
\text { Status }\end{array}$ & Public & Private & Private \\
\hline 2 & $\begin{array}{l}\text { Responsible } \\
\text { Foundation }\end{array}$ & - & $\begin{array}{l}\text { School under the } \\
\text { auspices of the } \\
\text { professional } \\
\text { organization of } \\
\text { teachers } \\
\text { Foundation, } \\
\text { namely Indonesian } \\
\text { teacher association } \\
\text { (PGRI) }\end{array}$ & $\begin{array}{l}\text { School under } \\
\text { the auspices of } \\
\text { the Taman } \\
\text { Siswa } \\
\text { Foundation }\end{array}$ \\
\hline 3 & $\begin{array}{l}\text { Status } \\
\text { principals }\end{array}$ & $\begin{array}{l}\text { Civil } \\
\text { Servant }\end{array}$ & $\begin{array}{l}\text { Functional civil } \\
\text { servants who are } \\
\text { assigned to private } \\
\text { schools, which was } \\
\text { appointed by the } \\
\text { teacher association } \\
\text { foundation (PGRI) }\end{array}$ & $\begin{array}{l}\text { Foundation } \\
\text { Permanent } \\
\text { Teacher who is } \\
\text { appointed as } \\
\text { the principal }\end{array}$ \\
\hline 4 & $\begin{array}{l}\text { The number } \\
\text { of students }\end{array}$ & 1402 & 816 & 2095 \\
\hline
\end{tabular}

${ }^{1}$ Yin, R.K., Case Study Research: Design and Methods. Beverly Hills, Chicago :Sage Publication, Inc, 1987
TABLE II. CONT.

\begin{tabular}{|c|c|c|c|c|}
\hline 5 & $\begin{array}{l}\text { Expertise } \\
\text { Program }\end{array}$ & $\begin{array}{l}\text { Archictect } \\
\text { ure } \\
\text { Engineerin } \\
\text { g Program } \\
\text { (TGB), } \\
\text { Light } \\
\text { Vehicle } \\
\text { Engineerin } \\
\text { g (TKR), } \\
\text { Motorcycl } \\
\text { e } \\
\text { Engineerin } \\
\text { g (TSM), } \\
\text { Computer } \\
\text { Network } \\
\text { (TKJ) and } \\
\text { Multimedi } \\
\text { a (MM) }\end{array}$ & $\begin{array}{l}\text { Light Vehicle } \\
\text { Engineering } \\
\text { (TKR), Motorcycle } \\
\text { Engineering } \\
\text { (TSM), Computer } \\
\text { Engineering and } \\
\text { Networks (TKR) } \\
\text { and the Network } \\
\text { Computer } \\
\text { Industries } \\
\text { Engineering, } \\
\text { Electrical } \\
\text { Engineering (TEI) } \\
\text { and Tools } \\
\text { Engineering (TP) }\end{array}$ & $\begin{array}{l}\text { Utilization of } \\
\text { Electric Power } \\
\text { Engineering, } \\
\text { Mechanical } \\
\text { Engineering, } \\
\text { Automotive } \\
\text { Mechanic } \\
\text { Engineering } \\
\text { and Computer } \\
\text { Engineering } \\
\text { and Networks }\end{array}$ \\
\hline
\end{tabular}

Researcher conducts the single case analysis in the three cases and then analyzed by cross cases. When analysis of a single case of researcher uses interactive model analysis, then when the cross-case analysis using the constant comparative analysis.

\section{DISCUSSION}

This research resulted in three major focus related to the social exchange in cooperation vocational high school and Business and Industry i.e.: the reward and cost, the level of relations in cooperation, and the actors who involved in.

\section{A. Reward and Cost}

The essential cooperation emerge from the interaction between an individual or group with individuals or other groups to achieve their goals. Sources of such relationships from the perspective of social exchange theory or Social Exchange Theory commonly abbreviated SET comes from two things: reward or reinforcement and cost. Here is a further explanation regarding the rewards and costs in the related Vocational High School 1 Mojokerto, Taman Siswa Vocational High School Magersari, PGRI Vocational High School Mojokerto with Business and Industry in Mojokerto and the surrounding areas.

All of these schools are schools that have the greatest public interest in Mojokerto. This is indicated by the number of students who enroll each year is always high. Selection of diverse expertise program also adds its own interest for the community. Each vocational program can be presented in Table III below. 
TABLE III. Vocational High School and Each Program skills

\begin{tabular}{|c|c|}
\hline Vocational High School & Expertise Program \\
\hline Vocational High School 1 Mojokerto & $\begin{array}{l}\text { Architecture } \\
\text { (TGB), Lngineering } \\
\text { Engineering (TKR), Motorcycle } \\
\text { Engineering (TSM), Computer } \\
\text { Network (TKJ) and Multimedia } \\
(\mathrm{MM}) .\end{array}$ \\
\hline $\begin{array}{l}\text { Taman Siswa Vocational High } \\
\text { School Magersari }\end{array}$ & 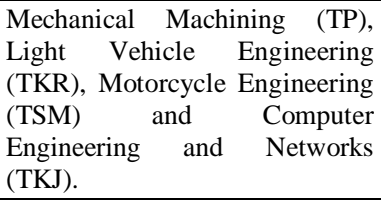 \\
\hline $\begin{array}{l}\text { PGRI Vocational High School } \\
\text { Mojokerto }\end{array}$ & $\begin{array}{l}\text { Power Installation Engineering } \\
\text { (TITL), Light } \text { Vehicle } \\
\text { Engineering (TKR), Mechanical } \\
\text { Engineering (TPM), and } \\
\text { Computer Network (TKJ) }\end{array}$ \\
\hline
\end{tabular}

The expertise program requires a certain skill competencies that must be achieved by the graduates. Through the expertise program, the characteristics can be mapped in the field business and industry as a partner.

Vocational High School Mojokerto, Taman Siswa Vocational High School Magersari, and PGRI Vocational High School Mojokerto need business industries which able to meet the needs in the implementation of PSG, especially on the activities of the industrial working practices (prakerin) and the distribution of graduates as candidates. The three Vocational School has limitations in the infrastructure, real working knowledge, and field experience for students. As an effort to maximize the education provision. These deficiencies can be obtained by carrying out industrial working practices activities in business industries program that is relevant to their expertise. Not only that Vocational High School Mojokerto, Taman Siswa Vocational High School Magersari, and PGRI Vocational High School Mojokerto also need a current business industries curriculum to increase student competence. The combination of school curriculum with the businessindustry curriculum give broader knowledge and skills. Meanwhile each years vocational high school produced hundreds of graduates, Vocational High School 1 Mojokerto 460 graduates, Taman Siswa Vocational High School Magersari 260 graduates, and PGRI Vocational High School Mojokerto about 300 graduates. It can be the opportunities and threats for the three Vocational High School. Being able to generate opportunities for diverse competencies graduates so that it can compete with other candidate workers. Be a threat if the graduates are not fully absorbed on relevant business industries so that adds to the classic problem of the link and match between vocational high school with business-industries. As revealed by Roxana $^{2}$ that Vocational High School students should understand their role in producing competent candidates

2 Roxana, H., "Skills mismatch of the young people at the european level", Annals of The University of Oradea: Economic Science, Vol 25, pp 431-439, 2015 workforce and business industries help distribute it, so there is a direct link between the each other.

Similarly with business and industry also have limitations. Business and industry need a skilled and competent workforce. Business and industry do not necessarily do the hiring of workers without analyzing how the characteristics of the labor candidates required, including educational background owned by candidate workers. Furthermore Business and industry as a profitoriented organization requires a good image in the community so that people increasingly appreciate the existence of Business and industry and the trust of goods and services produced by business and industry. This will give more benefits rather than just produce goods and services without significantly involved in community life.

Based on the description can be known that the cooperation required by an individual or group because each has limitations in fulfillment of resources and orientation gain, both material or symbolic. There are two main factor that actors doing in social exchange i.e.: the limited resources and social institutions ${ }^{3}$. Not only that in a previous study conducted by Kilbrink ${ }^{4}$, entitled "Transfer of Knowledge in vocational education: a Narrative study in Swedish Upper Secondary School "also discusses the limitations between vocational education and business and industry in Sweden, which both need each other so as to cooperate to meet the needs of each. Also explained that basically the cooperation between vocational schools with business and industry in Sweden is not necessarily used schools and business and industry to make a profit but both consciously to prepare students to be candidates for a competent workforce by providing the proper learning environment. Based on the presentation, in the cooperation context, the school and the business and industry should really understand what is needed to one another and how they meet those needs. As limitations Vocational High School 1 Mojokerto, Taman Siswa Vocational High School Magersari, PGRI Vocational High School Mojokerto, and business and industry which promote the cooperation between the two sides.

Furthermore, how efforts should be made so that the cooperation can run as expected in which both sides can fulfill their needs. The roots of social exchange theory is influenced by two basic concepts, namely the social exchange based on considerations of reward and cost. Prize is determined by the ability to reinforce the behavior, while the cost of reducing the possibility of behavior ${ }^{5}$. Based on two basic concepts of the key assumptions in the SET can be summarized as follows: (1) exchange is a representation from social behavior, (2) the reward is a target that is always

\footnotetext{
${ }^{3}$ Ritzer, G and Goodman, D.J. , Teori Sosiologi Modern, Jakarta: Kencana, 2008

${ }^{4}$ Kilbrink, N, "Transfer of knowledge in vocational education: a narrative study in swedish upper secondary school", International Journal of Education, Vol 4, 2, pp 519-535, 2013
}

${ }^{5}$ Ritzer, G and Goodman, D.J. , Teori Sosiologi Modern, Jakarta: Kencana, 2008 
maximized and the cost or risk is always minimized or even avoided by individuals, (3) every individual strives to provide feedback to the person who had given him reward. At this level it is clear that SMK 1 Mojokerto, Taman Siswa Vocational High School Magersari, PGRI Vocational High School Mojokerto, and business industries also issued a cost to get the expected reward.

As an effort to pursue good cooperation, 1 Vocational High School Mojokerto, Taman Siswa Vocational High School Magersari, and PGRI Vocational High School Mojokerto with business-industries made a deal that is written in the Memorandum of Understanding (MoU). The MoU contains the rights and obligations of both parties working together. Rights are reward that is expected while obligation is costs to be released. As limitations by both sides as previous, so the cooperation Vocational High School 1 Mojokerto, Taman Siswa Vocational High School Magersari, and PGRI Vocational High School Mojokerto with business-industries tried to meet the needs of their each cooperation partners. Cost released by Vocational High School 1 Mojokerto, Taman Siswa Vocational High School Magersari, and PGRI Vocational High School Mojokerto is to facilitate the recruitment of business-industries workers at the school, helping business-industries in the distribution of job information through the Special Job Information (BKK), to facilitate the another activities organized by businessindustries. Indirectly through the activity Vocational High School 1 Mojokerto, Taman Siswa Vocational High School Magersari, and PGRI Vocational High School Mojokerto has shown to the community involvement businessindustries concerned that business-industries obtain a positive image. Reward obtained when graduate is absorbed, implementation of practicum activities activities well, real work experience in the field, to increase the competence of graduates.

Cost released is business-industry facilitate industrial practicum activities that held by schools, provide industrial practicum curriculum, provide facilities and infrastructure practicum activities in the workplace. While the reward obtained business-industries in the form of a positive image in the community and obtain competent workforce as expected.

Based on the above description it appears that profit orientation has become stimuli in cooperation. Both Vocational High School and Business-Industry have limitations so it is important for them fulfill their needs mutually. This is exactly what makes Vocational High School and Business-Industry perform certain actions as agreed in the MoU. The limitation of the needs fulfillment raises the cooperation includes a number of positive and negative sanctions that encourage actors to perform certain actions and avoid other actions ${ }^{6}$.

Business and industry with all its resources and as a profit organizations can easily obtain cooperation partners. Logically Vocational High School needs more

${ }^{6}$ Friedman, D and Hechter, M., The Contribution of Rational Choice Theory To Macrosociology Research, In Sosiological Theory, 1998
Business and industry to meet the needs in education. But in this case, Vocational High School 1 Mojokerto, Taman Siswa Vocational High School Magersari, and PGRI Taman Siswa Mojokerto have high bargaining power so that businesss-industry competes to organize the cooperation with the three schools. The advantages of the three schools as a bargaining power that lies in the A accreditation and ISO 9001: 2008 which has been accepted i.e.:Vocational High School 1 Mojokerto, Taman Siswa Vocational High School Magersari, and PGRI Vocational High School Mojokerto. This makes the three of these schools are favorite Vocational High School in Mojokerto. This is consistent with that proposed by Thibaut and Kelley that is social exchange has a function of interdependence ${ }^{7}$. This interdependence emerge the power concept, namely the dependence of a person against another to achieve the final result as a common goal. The same matter was stated by Roloff states that the guiding of the relationship is progressing well as the personal interest of both parties ${ }^{8}$. When the reward was positively received as reinforcement for certain behavior, then the person will tend to repeat it again to get a positive reward. Based on the information it is concluded that the reinforcement is a consequence to reinforce the behavior.

On the SET one party provides cost in order to get a reward from the other party, if it is associated with reward behavioristic theory then this is a positive reward as reinforcement of behavior. As cooperation between Vocational High School 1 Mojokerto, Taman Siswa Vocational High School Magersari, and PGRI Vocational High School Mojokerto with Business-Industries are the laws of equilibrium appliedd, meaning that not only one party that provides cost and get a reward, but the other party also applies equally provide cost and got reward.

\section{B. Relationships Level in Cooperation}

Cooperation conducted Vocational High School 1 Mojokerto, Taman Siswa Vocational High School Magersari, and PGRI Vocational High School Mojokerto with business-industries can be continously collaboration or cannot continue. It is as a consequence of the cost released and the reward received by both parties. Determining the sustainability of cooperation is performed by analyzing the results of the evaluation of the cooperation, which is used as input for the planning of further cooperation. If the reward was not obtained in accordance with the cost released, where the cost is greater than the reward, the Vocational High School 1 Mojokerto, Taman Siswa Vocational High School Magersari, PGRI Vocational High School Mojokerto and business-industries has the right to decide or not to continue the cooperation. Thibaut and Kelley that each

\footnotetext{
7 Joice, Teori Pertukaran Sosial oleh John Thibaut \& Harold Kelley, Jakarta: Universitas Trisakti, 2002

${ }^{8}$ Rice, C., Handbook of Social Psychology, California: Stanford University, 2003
} 
individual will stay in a relationship only as long as the relationship is quite satisfactory in terms of reward and cost ${ }^{9}$

The results of the evaluation of cooperation analysis can be used as a planning material, can be done by looking at the relationship between the level of satisfaction of Vocational High School 1 Mojokerto, Taman Siswa Vocational High School Magersari, and PGRI Vocational High School Mojokerto with business-industry. This type of relationship and the level of relationship satisfaction can be seen in Table IV by Rice as follows.

TABLE IV. TYPE OF RELATIONSHIP AND SATISFACTION LEVEL ${ }^{10}$

\begin{tabular}{|c|c|}
\hline $\begin{array}{l}\text { Relative Value of Outcome, } \mathrm{CL}, \\
\mathrm{CL} \mathrm{L}_{\text {alt }}\end{array}$ & State of The Relationship \\
\hline Outcome $>\mathrm{CL}>\mathrm{CL}_{\text {alt }}$ & Satisfying, Stable, Dependent \\
\hline Outcome> alt $\mathrm{CL}>\mathrm{CL}$ & Satisfying, Stable, Nondependent \\
\hline Alt $\mathrm{CL}>\mathrm{CL}>$ Outcome & $\begin{array}{l}\text { Not Satisfying, Break relationship, Happy } \\
\text { elsewhere }\end{array}$ \\
\hline $\mathrm{CL}_{\text {alt }}$ Outcome $>\mathrm{CL}$ & Satisfying, Unstable, Happier elsewhere \\
\hline $\mathrm{CL}>\mathrm{CL}_{\text {alt }}$ Outcome & $\begin{array}{l}\text { Not satisfying, relationship Break, } \\
\text { Continue unhappy }\end{array}$ \\
\hline $\mathrm{CL}>$ Outcome $>\mathrm{CL}_{\text {alt }}$ & $\begin{array}{l}\text { Highly unsatisfying, Can 't breakaway, } \\
\text { Dependent and unhappy }\end{array}$ \\
\hline
\end{tabular}

Based on the above table, it can be presented on three areas: (a) Comparison Level (CL) is a standard for representing how people feel about what should be acceptable in terms of reward and cost of relationship; (b) Comparison Level for Alternatives ( $\mathrm{CL}_{\text {alt }}$ is how individuals evaluate a relationship based on what alternatives they have from a relationship; and (c) Outcome is the result of a relationship or reward received. So all components will form relationships with different patterns according to the level of each component, as described in the table above.

Most of the cooperation undertaken Vocational High School 1 Mojokerto, Taman Siswa Vocational High School Magersari, and PGRI Vocational High School Mojokerto with business-industries related is on the first level of relationship there is satisfaction, stable, and interdependence. But there is also cooperation did not continue because of certain things.

Cooperation is not derived from the continued cooperation that does not have obvious MoU, meaning that the rights and obligations vocational High School and Business- Industries is not given properly. Usually cooperation not accompanied $\mathrm{MoU}$ is not so binding on both parties. For example, cooperation conducted by SMK 1 Mojokerto with Metro TV. The cooperation in the form of work practicum activities, but not every period of Metro TV involved to facilitate practicum activities because unobvious agreement and no MoU underlying the cooperation. This means that although Vocational High School 1 Mojokerto and Metro TV provides cost and get a reward, but the price

9 Joice, Teori Pertukaran Sosial oleh John Thibaut \& Harold Kelley, Jakarta: Universitas Trisakti, 2002

${ }^{10}$ Rice, C., Handbook of Social Psychology, California: Stanford University, 2003 (worth) in the joint is not appropriate. The relationship cost, reward, and worth can be described in Figure I below.

FIGURE I. RELATIONSHIP COST, REWARD, AND WORTH

\begin{tabular}{|l|}
\hline Worth $=$ Reward - Cost \\
Worth : value in a relationship \\
Reward : reward or accepted positive element \\
Cost : cost or negative element released
\end{tabular}

Reduction of cost and reward the will generate a worth i.e.: value or level of relationship, which means one can continue the relationship, or not by the value or level of relationship generated.

This is also supported by Lawler where there is often a relationship of social exchange are not balanced and those who want something from the party but do not have the appropriate rewards will make adjustments together, that is what causes the power and dependability in one party or even discontinuation of cooperation ${ }^{11}$. Then Malcom ${ }^{12}$ when there is an imbalance in the cooperation, the parties in the collaboration can be: (a) refusing even with the risk of not getting anything; (b) try to have another source that can be used with the same values; (c) seek what is needed at the other alternatives so that there is a relationship of interdependence; and (d) the use of violence or physical force to deprive those who have such resources. In this study, Vocational High School 1 Mojokerto, Taman Siswa Vocational High School Magersari, PGRI Vocational High School Mojokerto and business-industries often use the steps in points (b) and (c), which is looking to other sources to meet the needs or find an alternative in relation to remain interdependent one another.

Relations of cooperation between Vocational High School 1 Mojokerto, Taman Siswa Vocational High School Magersari, and PGRI Vocational High School Mojokerto with Business-Industry sustained when seen from the type of social exchange, an exchange that happened was a productive exchange where both sides understand each other's position so that the cooperation can provide rewards as expected. Here is Figure II by Emmerson ${ }^{13}$ that indicates the type of social exchange.

${ }^{11}$ Lawler, E.J., "An affect theory of social change", American Journal of Sociology, Vol 107, pp 321-352, 2001

12 Malcom, W., Modern Sociological Theory, London: Sage Publications, 1994

13 Waters, M., Modern Sociological Theory, London: Sage Publication, 2004 
PRESS

FIGURE II. TYPES OF SOCIAL EXCHANGE

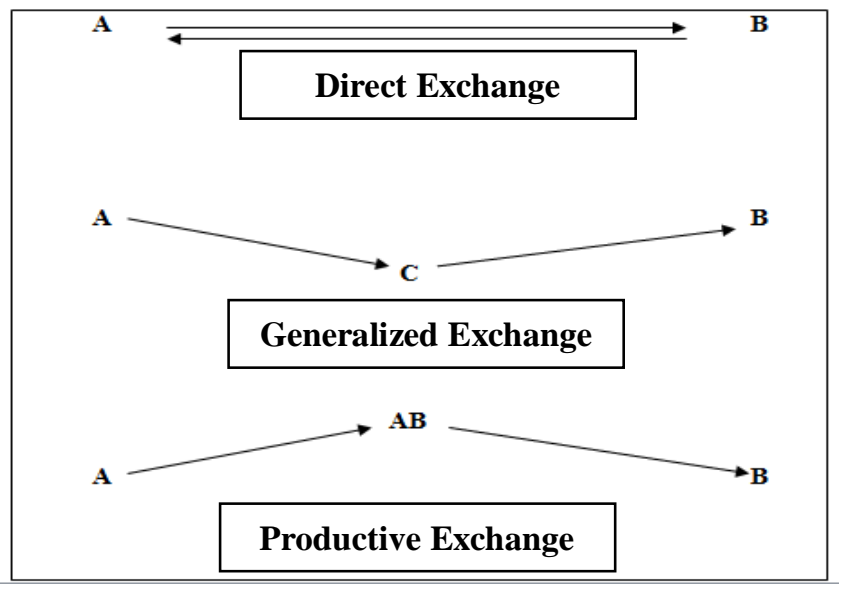

Productive exchange is realized because each party understands whether he is a cost giver at any one time and whether as a reward recipient. Then simultaneously received the maximum reward. It shows approriate worth for reward obtained with a lower cost.

\section{Actors Involved}

Community involvement in education is an effort to empower communities in the development of education, which means involving the community in planning, implementation, and monitoring of education. As the involvement of business-industries in cooperation with Vocational High School 1 Mojokerto, Taman Siswa Vocational High School Magersari, and PGRI Vocational High School Mojokerto. Business-Industries at first was to meet competent workforce and a good image in the community, but the essence business-industries as an cooperation actor has obligation to involve in performing education. The public can be grouped into three, namely the community of parents (parents who have children still in school), organized communities, and society at large. Organized community groups e.g.: social, political, religious, and business-industries included in this organizational group.

There are three main areas of community involvement in education in schools, ie. budgeting, school personnel / staff selection, and curriculum development ${ }^{14}$. In this case the business and industries assist in curriculum development, industrial working practicum implementation, and absorb the graduates produced by Vocational High School 1 Mojokerto, Taman Siswa Vocational High School Magersari, and PGRI Vocational High School Mojokerto. So that the involvement of business and industries in co-operation can improve the efficiency and effectiveness of the school in promoting growth and development of the quality of the learning process of students, promote quality of life and promote understanding and public interest in the program activities at the educational institution.

${ }^{14}$ Grant, Carl. A., Community Participation in Education: School and the Symbolic uses of Community Participation. Boston, Allyn and Bacon, Inc, 1979
The next actor who plays a role in the cooperation is the Head of Vocational High School 1 Mojokerto, Taman Siswa Vocational High School Magersari, and PGRI Vocational High School Mojokerto. The school principal has a role in making innovation and initiate cooperation with businessindustries. Principals should actively stimulate all components of the school to always find the latest information about business-industries which has advancement very rapidly compared to Vocational High School itself. The big role school principals and the business industries actors presented by Isgoren ${ }^{15}$ which is a key role in cooperation vocational High School and industries business was one of them was the principal. Principals should be proactive and create innovations that can inspire teachers and staff relating to building cooperation with business industries. Also in order to maintain school existence as, principals as leaders is person in charge to establish a cooperative relationship with stakeholders, especially business industries ${ }^{16}$.

The role of head of the Vocational High School 1 Mojokerto, Taman Siswa Vocational High School Magersari, and PGRI Vocational High Mojokerto as described above in accordance with that proposed by Henderson $^{17}$, the principal needs to do four things to cooperate with the community, which is as follows: (1) Help community feel comfortable in interacting with school staff by creating a welcoming culture; (2) assist staff to see the value and advantages of working with the community and in Redefining what "involvement in school" means; (c) help staff to see the importance of taking time to plan involvement strategies; and (d) address barriers to family and community involvement. This is similar to Henderson statement concerning the principal as a key person to help and assist the school staff in developing cooperation $^{18}$.

Head of Vocational High School 1 Mojokerto, Taman Siswa Vocational High School Magersari, and PGRI Vocational High School Mojokerto as leaders and managers must be able to master management functions. Vocational High School 1 Mojokerto, Taman Siswa Vocational High School Magersari, and PGRI Vocational High School Mojokerto always conduct a needs analysis and use the results of evaluation of previous activities to determine current needs. Through needs analysis so the established

${ }^{15}$ Isgoren, N.C., "The importance of cooperation between vocational shool and industry", Procedia-Social and Behavioral Sciences, Vol 1, pp 1313-1317, 2009

${ }^{16}$ Salvioni, D., "The role of key actors in school governance: an italian evidence”, US-China Education Review, pp 881-897, 2012

${ }^{17}$ Handerson, A., A New Wave of Evidence: Family and Community Connection with School, Texas: Southwest Educational Development Library, 2002

18 Handerson, A., A New Wave of Evidence: Family and Community Connection with School, Texas: Southwest Educational Development Library, 2002 
cooperation is well planned and concept, so that sustainability can be guaranteed because it has done forecasting. Leadership that is adapted to the conditions of the school and the accountability of the Head of Vocational High School 1 Mojokerto, Taman Siswa Vocational High School Magersari, and PGRI Vocational High School Mojokerto make these three schools into favorite schools. As revealed Boethel ${ }^{19}$ that the key factors to create sustainable linkages of the school with the community is planning, leadership, accountability, capacity building, as well as the induction and succession planning. As in the study entitled "An In-depth Study on The Cooperation of Vocational Education and Companies in the DVT-Program to Identify Major Strongpoint in The Institution -Industry Linkages with Recommendation for The Enactkment of The New Vocational Education and Training Art" by Whattananarong ${ }^{20}$ explained that the principal and business industries representatives should know each needs so that they can work maximally to help each other. Through a needs analysis and evaluation of cooperation we can identify competency requirements of human resources and the availability of jobs as part of improving collaboration by a vocational school at business and industries.

Other actors who also play a role in the cooperation Vocational High School 1 Mojokerto, Taman Siswa Vocational High School Magersari, and PGRI Vocational High School Mojokerto with business-industries are parents. Parents can play a role in supporting the implementation of educational activities. Parents of students Vocational High School 1 Mojokerto, Taman Siswa Vocational High School Magersari, and PGRI Vocational High School Mojokerto have a high awareness to help provide education for their children. The parents who initiated the cooperation with business industries is often. There are some parents who become officers who authority or even have a business that is relevant to the membership program at each school. Voluntarily parents connect schools with concern business-industries. It is very helpful for the process of cooperation because it is facilitated and the school can establish cooperation maximally. For example in industrial work practicum activities, and the parents of students in PGRI Vocational High School Mojokerto has a workshop. Parents are welcome to conduct the work practicum activities for students in their own workshop.

The last actor is who has also important role implementation of the cooperation is the government. The government authorizes the school and community to conduct education together. Efforts made by the government

${ }^{19}$ Boethel, M., Diversity: Family and Community Connections with Schools, Texas: Southwest Educational Development Laboratory, 2003

${ }^{20}$ Whattananarong, K., "An in-depth study on the cooperation of vocational education and companies in the dvt-program to identify major strongpoint in the institution -industry linkages with recommendation for the enactkment of the new vocational education and training art", King Mongkut's Institute of Technology North Bangkok, pp 1-18, 1999 is increasing the synergy in optimizing policy coordination, in one of the preventive measures in the field of education as well curative. One obvious example is to increase the number of vocational schools that produce graduates ready to work. The impact policy in Mojokerto vocational schools growing bigger and the more demanded by the public. So it becomes a logical consequence for the government to contribute to the vocational launch cooperation with business-industries. If the government does not pursue this, the greatest impact felt by Vocational High School. As research conducted by Chen ${ }^{21}$ the "Study on Development Strategies of Vocational School in China" explained that the issue of vocational schools one of which comes from "lack of policies and regulations, imperfect management system. Reviews these drag factors to the low recognition of vocational education in order to build cooperation with Workplaces". This means that the low power of regulation and government policy can affect vocational school in maximizing the learning process so that the impact is a vocational school has low sale value. In this context it is clear that the government bring an important role in maximizing cooperation vocational and business and industries.

Steps to maximize cooperation require the synergy of three components, namely, vocational school, government and business-industries. In this regard, there are two approaches, namely the social and labor approach. First, the social approach is an approach that is based on community needs at this time. This approach focuses on the purpose of education and on equal access to education ${ }^{22}$. Social approach is also called the traditional approach to the development of education by providing institutions and facilities to meet the pressures to enter the school as well as allowing the provision of opportunities for students and parents freely. Secondly, the approach of employment. In this approach education activities directed at efforts to meet the national need for labor in the early stages of development which of course requires a lot of manpower at all levels and in various types of expertise ${ }^{23}$. What happens now is that the government is using labor approach based on national needs. So that vocational cooperation with business industries is a consequence that must become government responsible government. Vocational High School as a nonprofit educational institutions have different orientations with profit-oriented business-industries. In this case the government must be willing to be a mediator to establish policies that can be used as a legal basis and the norm to strengthen cooperation among Vocational High School with business industries.

So it can be emphasized again that the key actors in the cooperation between Vocational High School 1 Mojokerto,

${ }^{21}$ Chen, P., "Study on development strategies of vocational education in china", Journal of Education, Vol 10, pp.4-9, 2014

${ }^{22}$ UNESCO, Educational Planning: Approaches, Challenges, and International Frameworks, UNESCO, pp 45, 2010

23 Fasih, T., Linking Education to Labor Market Outcomes, Washington DC, World Bank, 2008 
Taman Siswa Vocational High School Magersari, and PGRI Vocational High School Mojokerto with business-industries are: (1) business-industries; (2) head of Vocational High School 1 Mojokerto, Taman Siswa Vocational High School Magersari, and PGRI Vocational High School Mojokerto; (3) the parents; and (4) government.

\section{IV.CLOSING}

\section{A. Conclusion}

Relations of cooperation betweenVocational high school 1 Mojokerto, Taman Siswa Vocational High SchoolMagersari, and PGRI Vocational High School Mojokerto with business and industries performed as better vocational education provision. If from the social exchange theory (SET), the cooperation arises because both sides have limitations and need others to meet those needs. On the one hand social exchange theory provides cost in order to get rewards from the other party. As happened in the cooperation between Vocational High School 1 Mojokerto, Taman Siswa Vocational High School Magersari, and PGRI Vocational High School Mojokerto with business-industries found the equalization law. Each party realized that not only one party that provides cost and get a reward, but the other party also applies equally provide cost and got a reward

The level of cooperation relationships formed Vocational High School 1 Mojokerto, Taman Siswa Vocational High School Magersari, and PGRI Vocational High School Mojokerto with business-industries have the satisfaction, stable, and dependability. It creates a productive exchange. Productive exchange realized because each party understand whether he as a cost giver at any one time and whether as a reward recipient. Then simultaneously reward received becomes big and bigger. So there is approriate worth because the reward can be obtained at a lower cost

In cooperation relationship High School 1 Mojokerto, Taman Siswa Vocational High School Magersari, and PGRI Vocational High School Mojokerto with business-industries, there are actors who play important role. The actors are: (1) business-industries; (2) Head of High School 1 Mojokerto, Taman Siswa Vocational High School Magersari, and PGRI Vocational High School Mojokerto; (3) the students parents; and (4) government. Each actor plays an important role and urgent functions for the cooperation sustainability with business-industries.

\section{B. Suggestion}

Here are some suggestions for related parties in the cooperation Vocational High School 1 Mojokerto, Taman Siswa Vocational High School Magersari, and PGRI Vocational High School Mojokerto with business-industries.

1) For the Head of Vocational High School 1 Mojokerto, Taman Siswa Vocational High School Magersari, and PGRI Vocational High School Mojokerto can maximize the society functions as an actor that helps provide education, particularly business-industries, by conducting regular meetings or public discussions so there will be the better public awareness of the higher school program.

2) For business industries can be involved in the planning, implementation, and evaluation of cooperation activities in order to foster a sense of belonging to the organization of vocational education and implement the cooperation is not only merely for the company interests or profit.

3) For students parents can be involved actively not only initiate the cooperation but also can provide ideas and insights for the better organization of vocational education.

4) For the government is expected to provide policies in vocational cooperation with businessindustries. This is a logical consequence of increasing the number of vocational school to meet the demand for labor in Indonesia.

\section{ACKNOWLEDGMENT}

Sincere gratitude is hereby extended to the following who never ceased in helping until this paper is structured:

1) Prof. A. Sonhadji, Ph.D for assistance and comments that greatly improved the manuscript;

2) Prof. Dr. Ali Imron, M.Si. M.Pd for sharing his time and positive insight;

3) Dr. H. Imron Arifin, M.Pd for the unwavering guidance;

4) and for the unwavering moral, emotional, and financial support of the proponents' family and friends.

Above all, utmost appreciation to the Almighty God for the divine intervention in this academic endeavor.

\section{REFERENCES}

[1] Boethel, M., Diversity: Family and Community Connections with Schools, Texas: Southwest Educational Development Laboratory, 2003

[2] Chen, P., "Study on development strategies of vocational education in china", Journal of Education, Vol 10, pp.4-9, 2014

[3] Fasih, T., Linking Education to Labor Market Outcomes, Washington DC, World Bank, 2008

[4] Friedman, D. and Hechter, M., The Contribution of Rational Choice Theory To Macrosociology Research, In Sosiological Theory, 1998

[5] Grant, Carl. A., Community Participation in Education: School and the Symbolic uses of Community Participation. Boston, Allyn and Bacon, Inc, 1979

[6] Handerson, A., A New Wave of Evidence: Family and Community Connection with School, Texas: Southwest Educational Development Library, 2002

[7] Isgoren, N.C., "The importance of cooperation between vocational shool and industry", Procedia-Social and Behavioral Sciences, Vol 1, pp 1313-1317, 2009

[8] Joice, Teori Pertukaran Sosial oleh John Thibaut \& Harold Kelley, Jakarta: Universitas Trisakti, 2002

[9] Kilbrink, N., "Transfer of knowledge in vocational education: a narrative study in swedish upper secondary school", International Journal of Education, Vol 4, page 519-535, 2013

[10] Lawler, E.J., "An affect theory of social change", American Journal of Sociology, Vol 107, pp 321-352, 2001 
[11] Malcom, W., Modern Sociological Theory, London: Sage Publications, 1994

[12] Rice, C., Handbook of Social Psychology, California: Stanford University, 2003

[13] Ritzer, G dan Goodman, D.J. , Teori Sosiologi Modern, Jakarta: Kencana, 2008

[14] Roxana, H., "Skills mismatch of the young people at the european level", Annals of The University of Oradea: Economic Science, Vol 25, pp 431-439, 2015

[15] Salvioni, D., "The role of key actors in school governance: an italian evidence", US-China Education Review, pp 881-897, 2012

[16] UNESCO, Educational Planning: Approaches, Challenges, and International Frameworks, UNESCO, page 45

[17] Waters, M., Modern Sociological Theory, London: Sage Publication, 2004

[18] Whattananarong , K., "An in-depth study on the cooperation of vocational education and companies in the dvt-program to identify major strongpoint in the institution -industry linkages with recommendation for the enactkment of the new vocational education and training art", King Mongkut's Institute of Technology North Bangkok, pp 1-18, 1999

[19] Yin, R.K., Case Study Research: Design and Methods. Beverly Hills, Chicago :Sage Publication, Inc, 1987 